\title{
Risk factors associated with the development of metabolic syndrome in children and adolescents
}

Fatores de risco associados ao desenvolvimento da síndrome metabólica em crianças e adolescentes

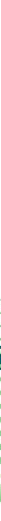

\section{Keywords}

Metabolic Syndrome X; Metabolic diseases; Risk factors; Risk assessment; Adolescent; Child

Descritores

Síndrome X metabólica; Doenças metabólicas; Fatores de risco; Medição de risco; Adolescente; Criança

Submitted

May 4, 2016

Accepted September 5, 2016
Corresponding author

Rumão Batista Nunes de Carvalho Cícero Duarte street, 905, 64607-670, Picos, PI, Brazil. rumaobatista@hotmail.com

DOI

http://dx.doi.org/10.1590/1982-

0194201600060

\begin{abstract}
Objective: To analyze the frequency of cardiovascular risk factors among children and adolescents, and their association with metabolic syndrome.

Methods: This was an analytical, quantitative study using a stratified sample of 421 children and adolescents from 9 - 19 years of age, selected by simple random sampling in 12 municipal public schools located in the Northeast region of Brazil. Physical inactivity and weight excess were the factors investigated. Metabolic syndrome was identified based on the adopted criteria for age.

Results: The prevalence of metabolic syndrome was 4.1\%; sedentary lifestyle was 30.2\%; and weight excess was $20.5 \%$. Higher values of body mass index were associated with the presence of the syndrome. Mean blood pressure, triglycerides, blood glucose, and waist circumference were increased in $11.9 \%, 20.9 \%, 0.5 \%$, $8.6 \%$ of the sample, respectively; $26.1 \%$ presented low HDL-c.

Conclusion: A substantial portion of those involved presented the risk factors assessed, as well as weight excess association with the components of the syndrome.

\section{Resumo}

Objetivo: Analisar a frequência de fatores de risco cardiovascular, entre crianças e adolescentes, e sua associação com a síndrome metabólica.

Métodos: Estudo analítico e quantitativo em uma amostra estratificada de 421 crianças e adolescentes de 9 a 19 anos selecionados por amostragem aleatória simples em 12 escolas públicas municipais localizadas na Região Nordeste do Brasil. Investigaram-se os fatores sedentarismo e excesso ponderal. A síndrome metabólica foi identificada a partir dos critérios adaptados para a idade.

Resultados: Houve prevalência de 4,1\% de síndrome metabólica. Eram sedentários 30,2\% e 20,5\% apresentaram excesso ponderal, sendo que valores mais elevados de índice de massa corporal estiveram associados à presença de síndrome. Pressão arterial média, triglicerídeos, glicemia e circunferência abdominal estavam aumentados em 11,9\%, 20,9\%, 0,5\%, 8,6\% dos investigados, respectivamente; $26,1 \%$ apresentaram HDL-c baixo.

Conclusão: Parcela substancial dos envolvidos apresentou fatores de risco avaliados, bem como associação do excesso ponderal com componentes da síndrome.
\end{abstract}

1 Universidade Federal do Piauí, Picos, PI, Brasil.

Conflicts of interest: there are no conflicts of interest to declare. 


\section{Introduction}

Metabolic syndrome is characterized by a set of cardiovascular risk factors related to the central deposition of fat and insulin resistance. The presence of at least three of the five following criteria qualify the individual as having metabolic syndrome: abdominal obesity, elevated triglycerides, low levels of high-density lipoprotein cholesterol (HDL-c), increased blood pressure, and increased fasting glucose. Although extensive discussion of the subject and its classification is well established in adults, the classification for children and adolescents is based on modifications of the criteria used in adults. Such modifications are references for identification of the syndrome in international research. ${ }^{(1-3)}$

The concern is with the presence of the syndrome features in children and adolescents. The prevalence of metabolic syndrome reaches $0.5 \%$ in children and $0.8 \%$ in adolescents, and at least $3.5 \%$ and $5.4 \%$ of these populations, respectively, present two components. Within this population, evidence also demonstrated a significant association between causative factors of metabolic syndrome and behavioral risk factors, physical inactivity and weight excess, emphasizing the importance of early diagnosis. ${ }^{(3-5)}$

Sedentary lifestyle is a conditioning factor on increasing secondary factors in students. Waist circumference, fasting blood glucose, total cholesterol and HDL-C appear altered when compared in active and sedentary groups. Within this behavior, a longer time watching television is associated with girls and obesity, and can be directly related to the development of cardiovascular risk factors, metabolic syndrome, and increasing age. ${ }^{(5-7)}$

Associated with sedentary lifestyle, weight excess is responsible for dyslipidemia and increased blood pressure in adolescents. In those individuals with weight excess, at least one secondary risk factor is found: the higher the body mass index (BMI), the greater the chance of altered biochemical tests, increasing the probabilities of having two or more risk factors in this group. ${ }^{(8,9)}$
Furthermore, obesity is the most prevalent pathophysiological cause of insulin resistance, which is associated with an increased number of cardiometabolic factors in adolescents, and reveals a predisposition for the subsequent development of metabolic syndrome, type 2 diabetes mellitus, and cardiovascular disease. ${ }^{(10)}$

Thus, this study aimed to analyze the frequency of cardiovascular risk factors among children and adolescents and their association with metabolic syndrome.

\section{Methods}

This was a quantitative, analytical study, conducted in 12 public schools located in northeastern Brazil. The population consisted of 1,452 elementary school students of both sexes. The sample size was estimated using the formula for finite populations, a confidence level of $95 \%$, a relative error of $8 \%$, population size, and prevalence. The sample included 421 participants stratified proportionally in the 12 schools and selected by simple random sampling, based on the established eligibility criteria.

The inclusion criteria were: being enrolled and attending school regularly; between $9-19$ years of age; and participating in all stages of the research. The exclusion criteria included: those unable to obtain the anthropometric measurements (pregnant and wheelchair users), carriers of any disease, or taking medications that could interfere with glucose or lipid metabolism, totaling 30 individuals. After losses and exclusions were recorded, new pairings were made, up to the number of children and adolescents estimated at each school.

A structured questionnaire containing personal and socioeconomic data, variables of risk for cardiovascular (sedentary lifestyle and weight excess) and metabolic syndrome (waist circumference, blood pressure, fasting blood glucose, triglycerides, and HDL-C). The parents of the participants were informed by telephone contact of the need to collect venous blood sample, 
with 12 hours of fasting to obtain laboratory information.

The socioeconomic classification, the Brazilian Economic Classification Criteria (CCEB), was used. ${ }^{(11)}$

The sedentary lifestyle was defined by the International Physical Activity Questionnaire (IPAQ-short version). ${ }^{(12)}$ Weight excess was classified by the weight obtained by means of a portable digital body scale with a maximum capacity of $150 \mathrm{~kg}$ and sensitivity of $100 \mathrm{~g}$, with the subject standing in the center of the equipment, wearing light clothes, barefoot, with feet together and arms extended down the body. The height was measured with a tape measure, precision of $0.5 \mathrm{~cm}$, fixed perpendicularly on a flat wall. With this data, BMI $\left(\mathrm{kg} / \mathrm{m}^{2}\right)$ was analyzed and classified, adjusted for age and sex of participants. $^{(13)}$

O perímetro da cintura foi obtida usando uma medida de fita inelástica colocado sobre a pele, com o objecto em posição vertical, no ponto médio entre a última costela e a borda superior da crista ilíaca, no final do movimento de expiração, e classificado como proposto ao público. ${ }^{(14)}$

Blood pressure was assessed by auscultation with properly calibrated aneroid sphygmomanometers and cuffs of different sizes, with the width of the bladder corresponding to $40 \%$ of the arm circumference and length of at least $80 \%$, and binaural stethoscopes. The appropriate cuff was based on the circumference of the arm of each participant. The blood pressure measurement procedure was performed with the individual in the sitting position, after five minutes of rest, with the cuff at heart level. Three measurements were taken with an interval of one minute between each one, and the mean score of the last two measurement was used. High blood pressure was determined by reference percentile values of arterial pressure, by sex, and in accordance with age and height percentiles. ${ }^{(15)}$

After blood collection, the samples were processed the same day, and the serum was analyzed in automated equipment to determine the serum lipid profile and blood sugar. Triglycerides,
HDL-c and the plasma glucose concentrations were determined by enzymatic methods, using reagents of biotech jobs, in the laboratory that was engaged for such a purpose.

Descriptive statistics were used, based on mean and standard deviation for continuous variables, and relative frequency for categorical variables. The Student's t-test for independent samples was used to compare continuous variables and the presence of metabolic syndrome. The Fisher's exact test assessed the association between the prevalence of the metabolic syndrome components associated to the variables: sex, age, BMI and physical activity (or absence of). The odds ratios were estimated, along with respective confidence intervals of 95\% (CI 95\%) for prevalence of isolated variables associated with metabolic syndrome (sedentary lifestyle, BMI, waist circumference, triglycerides and high blood pressure); those that presented a $\mathrm{p}<0.20$ were included in the logistic regression model. However, it was impossible to calculate the odds ratios for the variables hyperglycemia and low HDL-c, as they presented as zeros within the statistical calculation. A significance level of 5\% ( $p<0.05)$ was established for the final analysis. The data were processed using the IBM statistical package, Statistical Package for the Social Sciences (SPSS), version 20.0.

The study was registered in the Plataforma Brasil, under Certificado de Apresentação para Apreciação Ética, number (CAAE): 25431414.1.0000.5214.

\section{Results}

Among those evaluated, 59.6\% were female; $85 \%$ were 9 - 13 years old, and 15\% were between 15 - 17 , with a mean of $11.46 \pm 1.797 ; 45.1 \%$ self-reported as mixed race; $70.3 \%$ belonged to the lower social class; only $96.7 \%$ were studying; $98.3 \%$ were single, and $82.9 \%$ lived with their parents.

Weight excess was present in $20.5 \%$ of the subjects with a mean BMI of $18.2 \pm 4.0 \mathrm{~kg} / \mathrm{m}$. Approximately $30.2 \%$ were sedentary; of these, $74 \%$ were female $(\mathrm{p}=0.000)$ and $87.6 \%$ were between $9-13$ years of age $(\mathrm{p}=0.000)$. 
Among the metabolic syndrome-related variables, mean arterial pressure was elevated in $11.9 \%$. The mean systolic blood pressure $(98.3$ \pm 12.0 ) was elevated in $7.8 \%$, with a high prevalence in males $(60.6 \% ; \mathrm{p}=0.014)$ and the age group of 9 - 13 years $(66.6 \% ; \mathrm{p}=0.002)$. Regarding diastolic blood pressure $(62.7 \pm 12.0), 8.5 \%$ were elevated; of these, $63.8 \%$ were between 9 - 13 years of age $(p=0.000)$. As for a high value of triglycerides $(80.0 \pm 32.7)$, 20.9\% were associated with females $(70.4 \% ; \mathrm{p}=0.020)$ and those aged 9 - 13 years $(93.2 \% ; \mathrm{p}=0.016)$. Increased waist circumference $(67.0 \pm 9.6)$, blood glucose levels $(78.4 \pm 9.7)$, and low HDL-C $(46.6 \pm 8.9)$ were present in $8.6 \%, 0.5 \%$, and $20.9 \%$ of those investigated, respectively.

The prevalence of metabolic syndrome was $4.1 \%$, with $3.8 \%$ aged between $9-13$ years of age. Of the $13.1 \%$ of individuals with two components, 8.3\% were girls and 9.9\% were between 9-13 years of age. Those with three components (3.6\%) were boys in $2.1 \%$, and $3.3 \%$ were in that same age group (Table 1).

Table 1. Aggregation of components of metabolic syndrome (MS) in children and adolescents by sex, age group and cardiovascular risk factors (CRF)

\begin{tabular}{|c|c|c|c|c|}
\hline \multirow{2}{*}{ Variables } & \multicolumn{3}{|c|}{ Prevalence of component aggregates of MS } & \multirow{2}{*}{ p-value } \\
\hline & $\begin{array}{l}2 \mathrm{Cp} \\
\mathrm{n}(\%)\end{array}$ & $\begin{array}{l}3 \mathrm{Cp} \\
\mathrm{n}(\%)\end{array}$ & $\begin{array}{c}4 \text { or more } \mathrm{Cp}^{*} \\
\mathrm{n}(\%)\end{array}$ & \\
\hline Sex & $55(13.1)$ & $15(3.6)$ & $2(0.5)$ & 0.557 \\
\hline Male & $20(4.8)$ & $9(2.1)$ & $1(0.2)$ & \\
\hline Female & $35(8.3)$ & $6(1.4)$ & $1(0.2)$ & \\
\hline Age group & $35(8.3)$ & $6(1.4)$ & $1(0.2)$ & 0.366 \\
\hline $9-13$ & $42(9.9)$ & $14(3.3)$ & $2(0.5)$ & \\
\hline $14-17$ & $13(3.1)$ & $1(0.3)$ & - & \\
\hline \multicolumn{5}{|l|}{ CRF } \\
\hline Body mass index & & & & $<0.001 \dagger$ \\
\hline Underweight & $1(0.2)$ & - & - & \\
\hline Eutrophic & $32(7.5)$ & $2(0.5)$ & - & \\
\hline Overweight & $11(2.6)$ & $2(0.5)$ & $1(0.2)$ & \\
\hline Obesity & $11(2.6)$ & $11(2.6)$ & $1(0.2)$ & \\
\hline \multicolumn{5}{|l|}{ Physical exercises } \\
\hline Very active & $12(2.9)$ & $4(1)$ & $1(0.2)$ & 0.391 \\
\hline Active & $21(5)$ & $4(1)$ & $1(0.2)$ & \\
\hline Irregular active & $6(1.4)$ & $4(1)$ & - & \\
\hline Sedentary & $16(3.8)$ & $3(0.7)$ & - & \\
\hline
\end{tabular}

CRF - cardiovascular risk factors; MS - metabolic syndrome. *Presence of metabolic syndrome; $\uparrow \mathrm{p}$-value: significant for Fisher's exact test
Overweight and obesity, both with a prevalence of $2.6 \%$, were associated with the presence of two components of metabolic syndrome $(\mathrm{p} \leq 0.001)$. In those with three components, the association was higher in obese subjects. Only $0.5 \%$ presented four or more components, but with weight excess associated. With two components associated with metabolic syndrome, $3.8 \%$ were sedentary and with three, only $0.7 \%$.

Table 2 demonstrates that all the clinical continuous variables, except blood glucose, presented a significantly higher mean in the presence of metabolic syndrome.

Table 2. Clinical and biochemical characteristics of the study participants

\begin{tabular}{lcc|c}
\hline Variables & With MS & Without MS & p-value \\
\hline $\mathrm{n}$ (total) & 17 & 404 & \\
Body mass index , $\mathrm{kg} / \mathrm{m} 2$ & $25.2 \pm 4.2$ & $17.9 \pm 3.7$ & $<0.0001^{*}$ \\
Waist circumference, $\mathrm{cm}$ & $87.1 \pm 8.7$ & $66.1 \pm 8.6$ & $<0.0001^{*}$ \\
Systolic blood pressure, mmHg & $112.5 \pm 13.7$ & $97.7 \pm 11.5$ & $<0.0001^{*}$ \\
Diastolic blood pressure, mmHg & $71.8 \pm 15.7$ & $62.4 \pm 11.7$ & $0.001^{*}$ \\
Blood glucose, mg/dL & $78.0 \pm 9.4$ & $78.4 \pm 9.7$ & 0.866 \\
Triglycerides, $\mathrm{mg} / \mathrm{dL}$ & $132.2 \pm 38.6$ & $77.8 \pm 30.6$ & $<0.0001^{*}$ \\
\hline HDL-c, mg/dL & $33.1 \pm 4.5$ & $47.2 \pm 8.6$ & $<0.0001^{*}$ \\
\hline
\end{tabular}

p-value for Student t-test; MS - Metabolic syndrome; HDL-c - High-density lipoprotein - cholesterol

The likelihood analysis showed a higher odds ratio for waist circumference and an elevated BMI (Table 3). After logistic regression, in the final mod$\mathrm{el}$, the waist circumference variable was the one that really remained as a predictor of metabolic syndrome (high waist circumference: odds ratio: 81.0; 95\% CI: 21.6 to 303.0$)$.

Table 3. Association between the variables related to metabolic syndrome-related

\begin{tabular}{lccc}
\hline \multirow{2}{*}{ Variables } & \multicolumn{2}{c}{ Metabolic syndrome } & \multirow{2}{*}{-value } \\
\hline Sedentary & 0.484 & $\mathrm{Cl} \mathrm{95 \%}$ & \\
\hline High body mass index & 35.18 & $0.1-1.7$ & 0.251 \\
High waist circumference & 81.03 & $21.8-157.2$ & $<0.0001^{*}$ \\
High triglycerides & 20.81 & $5.8-74.2$ & $<0.0001^{*}$ \\
High blood pressure & 7.66 & $2.8-20.9$ & $<0.0001^{*}$ \\
\hline
\end{tabular}

${ }^{*} \mathrm{p}$-value - significant odds ratio; OR - odds ratio; CI95\% - confidence interval of $95 \%$

\section{Discussion}

The limitations of these results were related to the cross-sectional design, which does not allow the establishment of causal relationships even in sta- 
tistically significant associations. The classification criteria of the metabolic syndrome variables was based only on one study. Additionally, fasting of at least 12 hours is ensured by those involved in blood collection.

This study, however, brings an important epidemiological contribution to northeastern Brazil, revealing important data for the literature, especially due to the lack of studies that evaluate the frequency of cardiovascular risk factors among children and adolescents, and their association with the components of the metabolic syndrome. Thus, it should subsidize knowledge and support the planning and implementation of actions to prevent harm and/or promote health in this population, by nurses and other health care professionals, and may reduce the potential risks to these conditions presented.

Prevalence found in the literature ranged between 11.2 and $38 \%$ of children and adolescents presenting with excessive weight. Significant differences between genders were not observed, but it was associated with age, indicating that the higher the age, the higher the rates of excessive weight, which may predispose one to adult obesity. ${ }^{(16-18)}$

The prevalence of a sedentary lifestyle, compared to that recommended by the international literature, was higher, which differs from a national study that showed more than $60 \%$ of sedentary. Thus, it is understood that the practice of physical activity is still not experienced by students, especially girls. The data are worrisome and provide reasonable arguments for the design and implementation of actions aimed at public school children. The promotion of healthy practices, such as physical activity in children, provides significant benefits, such as weight control, attenuator effects on cholesterol levels and insulin resistance, regular blood pressure, well-being, and greater predisposition to active life during adolescence. ${ }^{(19-21)}$

Of the components of the metabolic syndrome, systolic blood pressure was statistically high in males $(\mathrm{p}=0.014)$, corroborating other results, ${ }^{(22)}$ but the prevalence increases considerably when assessing the average blood pressure of students, evidencing an increase in more than half of those who were evaluated. ${ }^{(23)}$

The HDL-c was the most prevalent of the metabolic changes, followed by hypertriglyceridemia. In international research, this component was the second risk factor for the development of metabolic syndrome, followed by triglycerides. ${ }^{(24)}$ In a national study, the value is lower than what has been described (13.3\%), and remains higher in males. ${ }^{(16)}$ The prevalence of low HDL-c, even small, should be reversed by actions that stimulate its increase among students, as increased levels of HDL-c decrease the relative risk for cardiovascular disease.

The hypertriglyceridemia mainly affects students of low socioeconomic class, and people in this condition are associated with a higher incidence and mortality from cardiovascular disease, probably due to the accumulation of risk factors. ${ }^{(25)}$

Change in waist circumference, although was not so prevalent as in other studies, was also identified, more frequently, in girls. ${ }^{(26)}$

The prevalence of metabolic syndrome in the current study was elevated. ${ }^{(25)}$ The highest prevalence in the group up to 13 years of age was confirmed by literature, in addition to the association with excessive weight. ${ }^{(24)}$ In other words, high BMI increases the presence of other factors. ${ }^{(26)}$

Thus, population-based studies adhere to the method and mark excessive weight as an important marker to identify metabolic syndrome and/or its components, and show a close association to its diagnostic criteria. ${ }^{(10,27)}$

Thus, the results presented, together with national and international literature, may suggest the addition of such cardiovascular factor to the components of metabolic syndrome, considering, in addition to increased waist circumference, excessive weight as a measurable factor of body fat in the diagnosis of this metabolic disorder.

The significantly higher mean of the clinical variables of those with metabolic syndrome indicate the association between them. In individuals with greatly increased waist circumference and BMI, the chance to present metabolic syndrome is, respectively, 81.03 and 35.18 times 
greater than in those without these alterations, followed by increased triglycerides and blood pressure. However, in the final logistic regression model, waist circumference is the only variable that actually remained predictive for metabolic syndrome. In general, these results are comparable to those found by other authors. ${ }^{(28)}$

\section{Conclusion}

In a substantial portion of children and adolescents, excessive weight was associated with a higher prevalence of two components of the syndrome. The prevalence of sedentary lifestyle was associated with being female and the age group, between 9 - 13 years of age. Except for blood glucose, all continuous clinical variables showed a significantly higher mean in the presence of metabolic syndrome, and the waist circumference variable was the only one that remained a greater predictor of metabolic syndrome.

\section{Acknowledgements}

To the Federal University of Piauí for the institutional support for conducting the study, and the Conselho Nacional de Desenvolvimento Cientifico e Tecnológico - CNPq; research funding by the Universal Notice / 2013).

\section{Collaborations}

Carvalho RBN, Nobre RS, Guimarães MR \& Teixeira SEXM contributed to the study design, analysis, data interpretation, article writing, relevant critical review of the intellectual content and final approval of the version to be published. Silva ARV contributed with article writing \& final approval of the version to be published.

\section{References}

1. Expert Panel on Detection, Evaluation, and Treatment of High Blood Cholesterol in Adults. Executive Summary of The Third Report of The National Cholesterol Education Program (NCEP) Expert Panel on Detection, Evaluation, And Treatment of High Blood Cholesterol In Adults (Adult Treatment Panel III). JAMA. 2001; 285(19):2486-97.
2. Cook S, Weitzman M, Auinger P, Nguyen M, Dietz WH. Prevalence of a metabolic syndrome phenotype in adolescents, findings from the Third National Health and Nutrition Examination Survey, 1988-1994. Arch Pediatr Adolesc Med. 2003; 157(8):821-7.

3. Wang $Q$, Yin J, Xu L, Cheng $H$, Zhao X, Xiang $H$, et al. Prevalence of metabolic syndrome in a cohort of Chinese schoolchildren: comparison of two definitions and assessment of adipokines as components by factor analysis. BMC Public Health. 2013; 13:249.

4. Xu H, Li Y, Liu A, Zhang $Q$, Hu X, Fang $H$, et al. Prevalence of the metabolic syndrome among children from six cities of China. BMC Public Health. 2012; 12:13.

5. Poeta LS, Duarte Mde F, Caramelli B, Jorge M, Giuliano Ide C. Effects of physical exercises and nutritional guidance on the cardiovascular risk profile of obese children. Rev Assoc Med Bras. 2013; 59(1):56-63.

6. Wennberg P, Gustafsson PE, Dunstan DW, Wennberg M, Hammarström A. Television viewing and low leisure-time physical activity in adolescence independently predict the metabolic syndrome in midadulthood. Diabetes Care. 2013; 36(7):2090-7.

7. Chehuen MR, Bezerra Al, Bartholomeu T, Junqueira NO, Rezende JA, Basso $L$, et al. Cardiovascular risk and physical activity practice in children and adolescents of Muzambinho/MG: Influence of gender and age. Rev Bras Med Esporte. 2011; 17(4):232-6.

8. Martins RV, Bozza R, Barbosa Filho VC, Dellagrana RA, Campos W. Comparative study of blood pressure in adolescents with different grades of nutritional status. Motricidade. 2012; 8(Suppl 2):734-41.

9. Alcântara Neto OD, Silva RC, Assis AM, Pinto EJ. Factors associated with dyslipidemia in children and adolescents enrolled in public schools of Salvador, Bahia. Rev Bras Epidemiol. 2012; 15(2):335-45.

10. Medeiros CC, Ramos AT, Cardoso MA, França IS, Cardoso AS, Gonzaga $\mathrm{NC}$, et al. Insulin resistance and its association with metabolic syndrome componentes. Arq Bras Cardiol. 2011; 97(5):380-9.

11. Associação Brasileira de Empresas de Pesquisa (ABEP). Critério de Classificação Econômica Brasil 2014 [Internet]. [cited 2016 Apr 28]. Available from: http://www.abep.org/codigosCondutas.aspx.

12. International Physical Activity Questionnaire (IPAQ). Questionário Internacional de Atividade Física - versão Curta [Internet]. [cited 2016 Apr 28]. Available from: http://www.celafiscs.org.br/index. php/contribuicoes-a-ciencia?task=callelement\&format=raw\&item_ id $=2 \&$ element $=411 \mathrm{cb} 000$-aca7-4b58-8f00-250dd6612f4b\&method $=$ download\&args $\% 5 \mathrm{~B} 0 \% 5 \mathrm{D}=0$.

13. World Health Organization (WHO). Multicentre Growth Reference Study Group. WHO child growth standards: methods and development. Length/height-for-age, weight-for-age, weight-for-length, weightfor-height and body mass index-for-age: methods and development [Internet]. Geneva: WHO; 2006. [cited 2016 Apr 28]. Available from: http://www.who.int/childgrowth/standards/technical_report/en.

14. Freedman DS, Serdula MK, Srinivasan SR, Berenson GS. Relation of circumferences and skinfold thicknesses to lipid and insulin concentrations in children and adolescents: the Bogalusa Heart Study. Am J Clin Nutr. 1999; 69(2):308-17.

15. Sociedade Brasileira de Cardiologia. Sociedade Brasileira de Hipertensão. Sociedade Brasileira de Nefrologia. VI Diretrizes Brasileiras de Hipertensão. Arq Bras Cardiol. 2010; 95(1 Supl.1):1-51.

16. Feliciano-Alfonso JE, Mendivil CO, Ariza ID, Pérez CE. Cardiovascular risk factors and metabolic syndrome in a population of young students from the National University of Colombia. Rev Assoc Med Bras. 2010; 56(3):293-8. 
17. Weber KE, Fischl AF, Murray PJ, Conway BN. Effect of BMl on cardiovascular and metabolic syndrome risk factors in an Appalachian pediatric population. Diabetes Metab Syndr Obes. 2014; 25(7):44553.

18. Venâncio PE, Teixeira CG, Silva FM. [Overweight, level of physical activity and food habits at school in the city of Anápolis-G0]. Rev Bras Ciênc Esporte. 2013; 35(2):441-53. Portuguese.

19. Briceño G, Fernández M, Céspedes J. [High prevalence of cardiovascular disease risk factors in a pediatric population]. Biomédica. 2015; 35(2):219-26. Spanish.

20. Cabrera TF, Correia IF, Santos D0, Pacagnelli FL, Prado MT, Silva TD, et al. Analysis of the prevalence of overweight and obesity and the level of physical activity in children and adolescents of a southwestern city of São Paulo. J Hum Growth Dev. 2014; 24(1):67-72.

21. Ribas SA, Silva LC. [Cardiovascular risk and associated factors in schoolchildren in Belém, Pará State, Brazil]. Cad Saúde Pública. 2014; 30(3):577-86. Portuguese.

22. Pollock NK, Bernard PJ, Gutin B, Davis CL, Zhu H, Dong Y. Adolescent obesity, bone mass, and cardiometabolic risk factors. J Pediatr. 2011; 158(5):727-34.
23. Vergetaki $A$, Linardakis $M$, Papadaki $A$, Kafatos $A$. Presence of metabolic syndrome and cardiovascular risk factors in adolescents and University students in Crete (Greece), according to different levels of snack consumption. Appetite. 2011; 57(1):278-85.

24. Wee BS, Poh BK, Bulgiba A, Ismail MN, Ruzita AT, Hills AP. Risk of metabolic syndrome among children living in metropolitan Kuala Lumpur: A case control study. BMC Public Health. 2011; 11:333.

25. Cruz IR, Freitas DA, Soares WD, Mourão DM, Aidar FJ, Carneiro AL. Metabolic syndrome and its association with socio-economic level in students. Rev CEFAC. 2014; 6(4):1294-301.

26. Papoutsakis C, Yannakoulia M, Ntalla I, Dedoussis GV. Metabolic syndrome in a mediterranean pediatric cohort: prevalence using International Diabetes Federation-derived criteria and associations with adiponectin and leptina. Metab Clin Exp. 2012; 61(2):140-5.

27. Silva SL, Madrid B, Martins CM, Queiroz JL, Dutra MT, Silva FM. [Influence of anthropometric factors and physical activity on blood pressure in adolescents from Taguatinga, Federal District, Brazil]. Motricid. 2013; 9(1):13-22. Portuguese.

28. Rosini N, Moura SA, Rosini RD, Machado MJ, Silva EL. Metabolic syndrome and importance of associated variables in children and adolescents in Guabiruba - SC, Brazil. Arq Bras Cardiol. 2015; 105(1):37-44. 


\section{Erratum}

In the article published in Acta Paul Enferm. 2016; 29(4):439-45, Carvalho RB, Nobre RS, Guimarães MR, Teixeira SE, Silva AR; "Risk factors associated with the development of metabolic syndrome in children and adolescents", should to publish the following errata:

\section{Substitute, in Methods section, the paragraph:}

"O perimetro da cintura foi obtida usando uma medida de fita inelástica colocado sobre a pele, com o objecto em posiçáa vertical, no ponto médio entre a ultima costela e a borda superior da crista ilíaca, no final do movimento de expiração, e classificado como proposto ao público. ${ }^{(14) ”}$

\section{For:}

"The waist circumference was obtained using an inelastic tape measure placed on the skin, with the subject in an upright position, in the midpoint between the last rib and the upper edge of the iliac crest at the end of the expiratory movement, and classified as proposed to the public. ${ }^{(14) ”}$

DOl: http://dx.doi.org/10.1590/1982-0194201700017

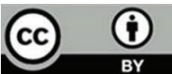

